\title{
Conduct and Belief: Public Employees' First Amendment Rights to Free Expression and Political Affiliation
}

\author{
Craig D. Singer $\dagger$
}

Two lines of Supreme Court decisions define the extent to which the Constitution protects public employees ${ }^{1}$ from dismissal for the exercise of their First Amendment rights. ${ }^{2}$ The first set of cases governs the employees' right to speak on matters of public concern; the second governs their right to political affiliation. However, the Court has not explained the relationship between these two approaches. As a result, lower courts have had difficulty determining which line of precedent applies to a case in which both overt expression and political affiliation might have influenced an employee's firing.

Consider, for example, the following hypothetical. Paula Partisan worked as a mid-level employee in the office of a city mayor. Last November, she supported her boss, Ida Incumbent, in Ida's re-election bid. During the campaign, a local newspaper accurately quoted Paula as saying: "As a member of the Platypus Party of America, I support Ida Incumbent over Carl Contender." Despite Paula's opposition, Carl won in a landslide, and fired Paula in his very first official act as mayor. Believing that her First Amendment rights have been violated, Paula sues. How should the court approach her case?

Either or both of the two lines of cases noted above might govern Partisan $v$ Contender. The first line, beginning with Pickering $v$ Board of Education, ${ }^{3}$ measures the extent of an employee's right

† B.A. 1990, Wesleyan University; J.D. Candidate 1993, The University of Chicago.

- By "public employees," this Comment refers only to those employees of federal, state, or local governments whom the government may fire for any reason (i.e., "at will") not violative of the Constitution. This Comment does not address civil service employees, whose First Amendment rights pose different constitutional questions.

2 The relevant text of the First Amendment reads:

Congress shall make no law ... abridging the freedom of speech, or of the press, or the right of the people peaceably to assemble, and to petition the government for a redress of grievances.

US Const, Amend I.

s 391 US 563 (1968). 
to speak on matters of public concern. In these cases, the Court has applied a balancing test which weighs the employee's First Amendment right against the government's interest in firing the employee for exercising that right. ${ }^{4}$

The second line of cases, beginning with Elrod $v$ Burns ${ }^{5}$ and clarified by Branti v Finkel, ${ }^{6}$ involves patronage dismissals. These cases address whether and to what extent an incoming public official may fire employees because of their political affiliation with the outgoing administration. ${ }^{7}$ In these affiliation cases, the Court has adopted a categorical rule that the First Amendment uniformly forbids patronage dismissals except when the employer can demonstrate that "party affiliation is an appropriate requirement for the effective performance of the public office involved." Unlike the overt speech cases, the political affiliation cases do not require lower courts to apply a case-by-case balancing test. ${ }^{9}$

The existence of two separate doctrines for similar situations has confounded lower courts. Courts differ on how to approach cases like Paula's, because both overt speech and political affiliation may have played a role in the employer's decision to fire the public employee. Which test the court will apply depends primarily on the court's view of the relationship between the two lines of Supreme Court precedent. The two lines of cases share, at least superficially, similar constitutional concerns and similar interests of the parties. Accordingly, several courts have concluded that the patronage cases are a narrow subset of the Pickering expression cases. ${ }^{10}$ These courts have interpreted all of the First Amendment cases as falling on a spectrum measured by the magnitude of the employer's interest in firing the expressive employee. ${ }^{11}$ By contrast, other courts have viewed the Pickering cases and the Elrod cases as governing entirely separate situations. ${ }^{12}$

- Id at 568.

s 427 US 347 (1976).

B 445 US 507 (1980).

7 Elrod, 427 US at 349; Branti, 445 US at 508.

8 Branti, 445 US at 518.

- For a discussion of the differences between the case-by-case balancing approach of Pickering and the "categorical" approach of Elrod, and for an analysis of the merits of these approaches, see Note, Politics and the Non-Civil Service Public Employee: A Categorical Approach to First Amendment Protection, 85 Colum L Rev 558 (1985).

${ }^{10}$ See McBee v Jim Hogg County, 730 F2d 1009, 1014 (5th Cir 1984)(en banc); Jones $v$ Dodson, 727 F2d 1329, 1334 n 6 (4th Cir 1984).

$11 \mathrm{McBee}, 730 \mathrm{~F} 2 \mathrm{~d}$ at 1014.

${ }^{12}$ See, for example, Barnes v Bosley, 745 F2d 501, 506 (8th Cir 1984). 
This Comment proposes a view of the relationship between Pickering and Elrod that relies upon a version of the "separate tests" paradigm. It concludes that the "unified spectrum" view lacks internal consistency, tends to unnecessarily restrict the scope of Elrod, and reads Elrod poorly. By contrast, a "separate tests" approach adheres more faithfully to the language and spirit of the precedents because the patronage cases and the speech cases involve different First Amendment rights and different state interests. These differences, in turn, explain the divergent standards the Court has used to judge the constitutionality of the state action.

Section I of this Comment describes Pickering and Elrod and their progeny. Section II explores several lower court approaches to cases in which the Pickering and Elrod tests conflict. Section III critiques these approaches and proposes a new way to resolve conflicts between the two lines of cases. Finally, Section IV proposes a causation test for determining which of the two precedents should govern ambiguous cases.

\section{Public Employees and the First Amendment}

\section{A. Overt Expression-The Speech Cases}

In Pickering $v$ Board of Education, ${ }^{13}$ the Supreme Court first articulated a general test for determining when a public employer may dismiss an employee for speaking on matters of public concern. In Pickering, a schoolteacher sued for reinstatement after the school board fired him for sending a letter critical of school board policy to a local newspaper. ${ }^{14}$ In an opinion by Justice Marshall, the Court held that the school board could not deprive Pickering of his right as a citizen to comment on matters of public concern. ${ }^{16}$ At the same time, however, the Court recognized that the state has an interest in regulating the speech of the teachers it employs. ${ }^{16}$ Accordingly, the Court adopted a balancing test to determine whether the state had constitutionally discharged Pickering. "The problem in any case," the Court wrote, "is to arrive at a balance between the interests of the teacher, as a citizen, in commenting upon matters of public concern and the interest of the State, as an

13391 US 563.

14 Id at 564 .

16 Id at 568.

18 Id. 
employer, in promoting the efficiency of the public services it performs through its employees." 17

Pickering determined the extent of the state's efficiency interest on the basis of several important considerations, including (1) the speech's effect on discipline by the employee's immediate supervisors, ${ }^{18}$ (2) its effect on harmony among the employee's coworkers; ${ }^{19}$ (3) whether the relationship between the employee and the employer against whom he spoke was a close one which required personal loyalty or confidence, ${ }^{20}$ (4) the speech's effect on the employee's job performance, ${ }^{21}$ and (5) its impact on the general operation of the employer's enterprise. ${ }^{22}$ The Court found that all of these factors favored the teacher on the facts of Pickering; therefore, the school board acted unconstitutionally in firing him. ${ }^{23}$

Fifteen years after Pickering, the case of Connick v Myers ${ }^{\mathbf{2 4}}$ revised and clarified the analysis in the earlier case. In an opinion by Justice White, the Court made explicit what it found to be implicit in Pickering: that the Pickering balancing test applies only when the employee's speech touches on a matter of public concern. ${ }^{25}$ "When employee expression cannot be fairly considered as relating to any matter of political, social, or other concern to the community, government officials should enjoy wide latitude in managing their offices, without intrusive oversight by the judiciary in the name of the First Amendment."26

Nevertheless, employee speech on matters of public concern still merits consideration under the Pickering balance. ${ }^{27}$ In this regard, the Connick court followed Pickering in recognizing that the state has an important interest in the efficiency of its public enter-

${ }^{17}$ Id.

18 Id at 570-71.

${ }^{18} \mathrm{Id}$.

${ }^{20}$ Id.

21 Id at 572-73.

22 Id at 573 .

${ }^{23}$ Id at 569-73.

24 461 US 138 (1983).

$2 s$ Id at 146.

${ }^{26}$ Id (emphasis added). In Connick, the Court held that a questionnaire distributed by an assistant district attorney did not, except for one question, involve matters of public concern, because the questionnaire primarily addressed the internal workings of her office. Therefore, her employer could fire her for distributing the questionnaire, without having to face the Pickering test, except with regard to the one question dealing with public matters. Id at 146-49, 154. After applying the Pickering test to that one question, the court resolved the balance in favor of the employer. Id at 149-54.

27 Id at 149-50. 
prise. ${ }^{28}$ Connick explained that the need for efficiency includes a state interest in avoiding employee expression that might "disrupt the office, undermine [the employer's] authority, and destroy close working relationships." 29

Still more recently, in Rankin $v$ McPherson, ${ }^{30}$ the Court reaffirmed the vitality of the Pickering test for cases in which the employee's expression involves matters of public concern. Justice Marshall, writing for the Court, held that a deputy constable spoke on a matter of public concern when she remarked, in response to learning of an assassination attempt on President Reagan, "If they go for him again, I hope they get him."31 Because the speech was of public concern, the Court held that the Pickering balancing test governed, and it resolved the balance in favor of the deputy. ${ }^{32}$

In balancing the employee's speech interest against the state's efficiency interest, the Rankin court expanded Pickering's description of the relevant factors for determining the weight of the state's interest. Specifically, the Court observed that "some attention must be paid to the responsibilities of the employee within the agency. The burden of caution employees bear with respect to the words they speak will vary with the extent of authority and public accountability the employee's role entails." 33 In other words, the more the employee's job requires confidentiality, policymaking, or public contact, the greater the state's interest in firing her for expression that offends her employer. ${ }^{34}$

\section{B. Political Affiliation-The Patronage Cases}

The Rankin criteria for the state's interest mirror some of the key issues in the patronage cases, which the Court decided in the years between Pickering and Connick. During this period, the Court issued two decisions that determined the extent of an incoming public official's ability to fire employees because of their political loyalty to the previous administration.

In Elrod v Burns, Justice Brennan's plurality opinion held that patronage firings infringe upon the First Amendment's guar-

${ }^{28}$ Id at 150-51. See Pickering, 391 US at 568.

${ }^{29}$ Connick, 461 US at 154.

so 483 US 378 (1987).

${ }^{31}$ Id at $381,386-87$.

32 Id at 388-89, 392.

${ }^{33}$ Id at 390.

34 Id at 390-91. In Rankin, the Court found a reduced state interest because the employee, although bearing the title of "deputy constable," performed the duties of a data entry clerk. Id at $380-81$. 
antee of free political belief and association..$^{35}$ To decide whether the firings were constitutional, Brennan applied a "heightened scrutiny" analysis: conditioning public employment on the employee's political affiliation "must further some vital government end by a means that is least restrictive of freedom of belief and association in achieving that end, and the benefit gained must outweigh the [infringement]." 36

The plurality in Elrod first looked to the state's asserted need for efficiency as a justification for patronage firings and determined that this need was not sufficient, in this situation, to survive heightened scrutiny. ${ }^{37}$ For three reasons, the plurality rejected the argument that workers who do not share the controlling administration's political views will not work efficiently. First, it argued, the inefficiency that inevitably results from wholesale patronage firings undercuts the efficiency justification. ${ }^{38}$ Second, despite the employer's fear that employees who belong to an opposing party may subvert the public enterprise's efficacy, the plurality held that "mere political association is an inadequate basis for imputing disposition to ill-willed conduct." ${ }^{39}$ Finally, the plurality held that the state could employ less drastic means than patronage firings to encourage employees to work efficiently. ${ }^{40}$

The plurality next examined the state's asserted interest in political loyalty. It agreed that the state might need politically loyal employees to ensure that "policies which the electorate has sanctioned are effectively implemented." ${ }^{41}$ Thus, a political loyalty interest might justify partisan firings-even where the state cannot advance a valid efficiency justification. This result is possible because the two interests, loyalty and efficiency, each advance a distinct governmental value. Efficiency protects the effective day-today operation of the public enterprise. Political loyalty, on the other hand, protects the political process from disloyal employees who may try to thwart the goals of the duly elected representatives. ${ }^{42}$

35 427 US 347,355 (1976).

36 Id at 363.

${ }^{37}$ Id at 364.

38 Id.

${ }^{39}$ Id at 365.

10 Id at 366. Brennan pointed specifically to the availability of "for cause" discharges and merit systems as less drastic means of ensuring efficiency in the government workforce. Id.

41 Id at 372.

42 Id at 367. 
Nevertheless, Justice Brennan determined that this government interest in political loyalty does not validate all patronage firings. Instead, because heightened scrutiny requires the state to employ the least restrictive alternative, courts should confine patronage dismissals to "policymaking" employees. ${ }^{43}$ This limitation adequately serves the state's interest because "[n]onpolicymaking individuals usually have only limited responsibility and are therefore not in a position to thwart the goals of the in-party." 44 Consequently, the constitutionality of a political firing turns on whether or not the court characterizes the employee as a policymaker. The state may fire a policymaker solely because of her political affiliation, but it may not do likewise with a nonpolicymaker. ${ }^{45}$

Concurring in the judgment, Justices Stewart and Blackmun addressed only the narrow question of "whether a nonpolicymaking, nonconfidential government employee can be discharged . . . upon the sole ground of his political beliefs." ${ }^{46}$ Like the plurality, they answered that question in the negative. ${ }^{47}$

Elrod, then, uses a one-dimensional test that differs substantially from the Pickering-Connick balancing test. While Pickering requires a lower court to balance the interests anew in each case, Elrod makes no such demand. Instead, Elrod requires lower courts to make a single, categorical determination: whether the employee is a policymaker.

In Branti v Finkel, ${ }^{48}$ the Court revised the test for determining which employees the state may discharge for their political affiliation. While maintaining a categorical distinction among employees as the means of determining the constitutionality of political firings, Justice Stevens's majority opinion set aside policymaking as the key consideration. ${ }^{49}$ Instead, he wrote, "the ultimate inquiry is ... whether the hiring authority can demonstrate that party affiliation is an appropriate requirement for the effective performance of the public office involved."

43 Id.

14 Id.

46 Id at 372 .

46 Id at 375 (Stewart concurring in the judgment).

47 Id.

445 US 507 (1980).

40 Id at 518.

so Id. This Comment will continue, for brevity's sake, to refer to employees as "policymakers" and "nonpolicymakers," but Branti's standard now defines those terms. 
clarification, the Court in Branti did not purport to alter the analysis or holding of the plurality in Elrod.5.

In the recent case of Rutan $v$ Republican Party of Illinois, the Court held that the rule in Elrod and Branti extends beyond patronage firings to "promotion, transfer, recall, and hiring decisions based on party affiliation and support ...." Th2 Thus, the Court has shown a willingness to broaden Elrod's protection of belief and associational rights beyond the precise facts of that case. ${ }^{53}$

\section{Lower Court Responses to Pickering-Ellod Clashes}

The Pickering and Elrod doctrines govern analytically similar situations in that both attempt to define the extent of a public employee's rights under the First Amendment. As a result of the doctrines' similarity, cases sometimes arise in which either test could arguably apply. Because these tests can lead to very different results in practice, a court's choice between Pickering and Elrod might well resolve the case. Unfortunately, lower courts faced with the problem have differed on the means of making this choice.

Circuit courts dealing with cases that arguably contain issues of both political affiliation and overt speech have reached a number of different conclusions about the interrelationship of the two doctrines. Viewed from a distance, however, these courts have tended toward one of two larger conceptions: either they have treated the two lines of cases as falling together on a single unified spectrum of public employee First Amendment rights, or they have treated the speech and affiliation precedents as two separate, although similar, doctrines.

\section{A. The Unified Spectrum Approach}

The "unified spectrum" approach, best exemplified by the Fifth Circuit's en banc decision in McBee $v$ Jim Hogg County, ${ }^{54}$ holds that Elrod and Branti comprise one narrow subset of a larger

62 Id.

s2 110 S Ct 2729, 2739 (1990).

s3 Justice Scalia, joined by the Chief Justice and Justice Kennedy, and joined in part by Justice O'Connor, dissented in Rutan, arguing that Elrod and Branti themselves were wrongly decided. Id at 2746-59 (Scalia dissenting). Justice Scalia's view may yet become the view of the Court; two members of the majority in Rutan, Justices Brennan and Marshall, have since retired.

s4 730 F2d 1009, 1014 (5th Cir 1984) (en banc). In McBee, a newly-elected county sheriff fired several deputies who had actively supported the ill-fated re-election campaign of his predecessor. Id at 1010. The court held that Pickering applied to this case because the deputies lost their jobs a result of more than mere private affiliation. Id at 1015. 
spectrum of employee First Amendment cases governed by Pickering and Connick. Under this view, cases arrange themselves on that spectrum based on the extent to which the employee's speech impairs the employer's enterprise. ${ }^{55}$ The patronage cases, which involve firings for purely private political affiliation, require no caseby-case weighing under the Pickering test, because they belong on the extreme end of the spectrum where the balance clearly favors the employee. ${ }^{56}$ Because the result of the balance is so clear, the Elrod court determined that the employee's interest will always prevail unless the employee is a policymaker whose incongruous political affiliation endangers the public enterprise. Therefore, the unified spectrum view regards Elrod as a case in which the Court applied Pickering itself, deriving from the balancing test a specialized application of the Pickering rule for political patronage cases. $^{57}$

Significantly, under the unified spectrum approach the scope of the patronage cases is extremely narrow. Because Elrod governs only the very extreme of the employee's side of the spectrum, it can only apply to cases of purely private political affiliation in which the employee never voiced her beliefs. ${ }^{58}$ Cases that involve any overt expression implicate a greater state interest than existed in Elrod or Branti, so that the balance no longer yields such a clear result that the court can apply Elrod-Branti without further analysis. In $M c B e e$, for example, the fired employees had actively supported the losing candidate in an election. This presence of overt expression led the Fifth Circuit to hold that Elrod did not control, and that Pickering was the correct test. ${ }^{59}$

ss Id at 1014.

so Id.

s7 See id. The Fourth Circuit has taken a similar view of the interrelationship of these two lines of Supreme Court decisions. In Jones $v$ Dodson, 727 F2d 1329 (4th Cir 1984), another case in which a newly-elected sheriff fired employees who had actively supported his opponent in the latest election, the court acknowledged in a footnote that the Elrod patronage cases comprise a narrow subset of the larger set of Pickering employee expression cases. Id at 1334-35 n 6 . At the same time, the court expressed reservations similar to those of the court in McBee that the patronage test is too rigid for those cases which involve any element aside from mere private political affiliation. Id. However, where $\mathrm{McBee}$ held that Elrod is inapplicable whenever the employee openly expressed her affiliation, the Jones court held that causation determines which test applies to an individual case. Id at 1336. Specifically, it held that if the motivation of the employer in firing the employee was purely one of political affiliation, then the Elrod-Branti test is the appropriate one, but if the employer was motivated "to any significant degree by overt speech activity by the public employee," then the Pickering test applies instead. Id.

ss See $\mathrm{McBee}, 730 \mathrm{~F} 2 \mathrm{~d}$ at 1014.

so Id at 1014-15. 


\section{B. The Separate Tests Approach}

In contrast to the unified spectrum approach, the "separate tests" approach holds that Elrod and Pickering govern separate and distinct situations. For the most part, courts that have taken this approach have not sought to justify it on a theoretical level, but have tried instead to distinguish the two doctrines on the facts.

Several circuits have adopted this view in one form or another. For example, the Eighth Circuit has declined to use Pickering to decide a case in which a newly-elected official fired several employees for supporting the losing incumbent in an election. ${ }^{\text {Bo }}$ The court held that Elrod's test applies to all cases of political affiliation, of which this was one. ${ }^{61}$ It did not discuss the possibility that Pickering might apply if the employees had openly expressed their support of the losing incumbent. In addition, the Eleventh Circuit has distinguished between cases of "employee expression," and cases of "raw political patronage" in which "employees are discharged en masse by a prospective employer or supervisor." ${ }^{\prime 2}$ Thus, although it has not explained how one distinguishes between the two in ambiguous situations, that court considers affiliation and speech to be entirely separate. ${ }^{63}$

\section{A Proposed Resolution}

It remains to be determined which, if either, of these approaches adheres most faithfully to the Supreme Court's precedent and to the proper resolution of mixed expression-affiliation cases. This section analyzes the alternatives and concludes that Elrod and Branti are properly seen as distinct from the overt expression cases, and not as a narrow subset of those cases. It concludes that in deciding which test applies in a given case, the inquiry should

Bo Barnes v Bosley, 745 F2d 501, 503 (8th Cir 1984).

${ }^{61}$ Id at 506. The court made this determination after a discussion of Pickering, in which it cryptically concluded that "[ $t]$ he Pickering balancing test need not be used in determining whether the First Amendment protects political affiliation." Id.

${ }^{62}$ Terry v Cook, 866 F2d 373, 376-77 (11th Cir 1989). The court further held that "[a] Ithough the cases may overlap in some areas, it is important to retain the distinction between actions that assert employees' right of expression and actions that challenge discharge decisions based on political patronage." Id at 377.

${ }^{83}$ Id. This separate tests approach has sometimes led these courts to narrow the application of Elrod and Branti. For instance, the Ninth Circuit has confined the reach of Elrod to cases in which an employee suffers because of party loyalty; it has held that the patronage cases do not apply to cases in which an employee opposes the incumbent personally in a non-partisan election. Thomas $v$ Carpenter, 881 F2d 828, 831 (9th Cir 1989). Ironically, this aspect of the separate test theory mirrors McBee's unified spectrum-both theories narrow the reach of Elrod. 
properly focus upon the fundamental distinction between conduct and belief.

\section{A. The Merits of the Unified Spectrum View}

Concededly, the unified spectrum approach makes intuitive sense. At first glance, the political affiliation protected in Elrod, Branti, and Rutan appears indistinguishable, for practical purposes, from the forms of political and social expression protected in Pickering, Connick, and Rankin. Both lines of cases involve First Amendment rights of public employees and both implicate similar interests of the state as an employer. Therefore, one might reasonably conclude that the same test should protect these two similar rights. From this conclusion it is but a short step to the proposition that the patronage cases represent a narrow subset of employee expression cases. Accordingly, the Court must have balanced the Pickering interests (albeit implicitly) and found the balance so lopsided that courts could henceforth apply a straightforward rule in similar cases.

1. Inconsistency with the patronage cases.

A closer look at the patronage cases, however, reveals serious problems with the unified spectrum approach. Most importantly, in viewing the patronage cases as an implicit application of Pickering, the spectrum approach is inconsistent with the precedent upon which it relies. Indeed, it is evident from Elrod that the Court decided the patronage cases very differently than the speech cases.

First, in deriving the test in Elrod, the plurality did not rely on Pickering. In fact, Justice Brennan mentioned Pickering just once-in a footnote. That footnote described in general terms the various conditions on public employment held to violate the First Amendment. ${ }^{64}$ If the Court truly intended to resolve Elrod by applying the Pickering test, one would expect at the very least that the Court would mention that test and identify its source.

Second, Elrod evaluated the employees' right to free political affiliation differently than Pickering evaluated their right to speak. While Pickering balanced the state's interest in the efficiency of its

s4 Elrod, 427 US at $358 \mathrm{n} 11$. The relevant text reads: "[m]ore broadly, the Court has held impermissible under the First Amendment the dismissal of a high school teacher for openly criticizing the Board of Education on its allocation of school funds." Id. 
public enterprise against the employee's free speech, ${ }^{65}$ Elrod eschewed balancing and applied instead a heightened scrutiny test. ${ }^{66}$ True, Brennan's definition of the heightened scrutiny standard included an element of balancing ("the benefit gained must outweigh the loss of constitutionally protected rights"). ${ }^{67}$ Nevertheless, his opinion focused on the other elements of that standard: a "paramount" the least restrictive means. ${ }^{70}$ The Pickering balance did not explicitly require either of these elements, but asked only whether the government's interest outweighed the employee's right. ${ }^{\text {11 }}$

Third, Elrod gave dispositive weight to a consideration that played only a small part in the Pickering test: the nature of the employee's job. Admittedly, Rankin held that the public and confidential nature of an employee's position affects the relevant weights in the Pickering balance, ${ }^{72}$ and Pickering itself cited the character of the relationship between the employer and employee as one element for a court to consider. ${ }^{73}$ Nevertheless, neither case indicated that these considerations alone should control the outcome. ${ }^{74}$ In sharp contrast, Elrod held that in the context of a patronage firing the nature of the employee's job and her relationship to the employer is not only relevant, but always dispositive..$^{75}$ Why, if Elrod merely applied the Pickering test, would it place so much more value upon this consideration than did Pickering or Rankin?

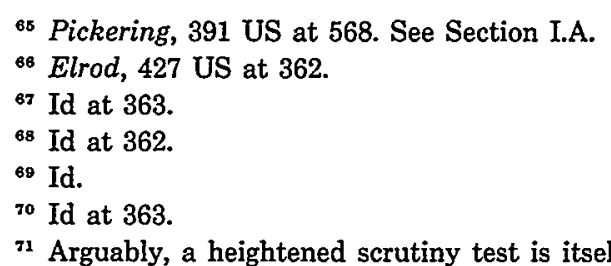
balance is heavily weighted toward the employee. We could view heightened scrutiny as a test that takes the value of the employee's right as a starting point and then articulates the requirements- $a$ vital government interest and a least restrictive alternative-that the state regulation must satisfy to "outweigh" that right. Nonetheless, even if we characterize the test in Elrod as a balancing test, it differs markedly from the straightforward balancing test in Pickering. The Pickering test directly weighs the state's interest against the employee's right, imposes no specific standards on either side, and gives neither side an explicit advantage at the outset.

72 Rankin, 483 US at $390-91$.

${ }^{23}$ Pickering, 391 US at 569-70.

${ }^{74}$ In fact, Pickering sharply rejected the notion of a categorical approach based upon the employer-employee relationship. The Court wrote, "[b]ecause of the enormous variety of fact situations in which critical statements by ... public employees may be thought by their superiors ... to furnish grounds for dismissal, we do not deem it either appropriate or feasible to attempt to lay down a general standard ...." Id at 569.

${ }^{78}$ Elrod, 427 US at $367,375$. 
Most importantly, Elrod cannot be seen as an application of the Pickering test because the two lines of cases implicate distinct government interests. Pickering balanced the employee's right to speak against the employer's interest in promoting the efficiency of the public enterprise. ${ }^{76}$ Elrod, on the other hand, held that this efficiency rationale cannot justify firing the employee for belief and association..$^{77}$ Instead, the plurality relied on an expressly separate interest: that of having politically loyal subordinates. ${ }^{78}$ Justice Brennan explicitly stated that this interest does not relate to the efficiency of the state enterprise. ${ }^{79}$ Rather, it protects representative government from persons who might try to obstruct "the implementation of policies of the new administration, policies presumably sanctioned by the electorate."

In sum, the patronage cases cannot be seen as a subset of the speech cases because (1) they do not rely on the speech cases as precedent; (2) they use a different method of analysis to judge the constitutionality of the employer's action; (3) they give greater weight to the nature of the employee's job; and (4) they involve a markedly different government interest. Therefore, the unified spectrum approach errs in interpreting Elrod as an application of the Pickering test-it is not a subset, but a separate and distinct legal doctrine.

\section{Narrowing Elrod's reach.}

The second weakness of the unified spectrum view is its tendency to narrow the reach of Elrod. The spectrum approach has this effect because first, it must rationalize Elrod's categorical test within the framework of Pickering, and second, it must impose Pickering's efficiency interest upon Elrod.

The unified spectrum approach sees Elrod as a member of the Pickering family-an appropriate stand-in when the Pickering balance clearly favors the employee. Thus, if Elrod is a subset of Pickering, then Pickering must govern Elrod and we must look to Pickering to judge Elrod's relationship to other First Amendment cases on the spectrum.

But the only benchmark that Pickering provides to measure the placement of cases on the spectrum is the state's interest in

${ }^{76}$ Pickering, 391 US at 568.

77 Elrod, 427 US at 359, 364-67.

78 Id at 367.

79 Id.

so Id. 
efficiency. This state's interest standard is the logical choice because it is the only variable considered in the Pickering line of cases: by contrast the employee's right is a constant and the public concern requirement is a simple threshold test unsuited to a broad spectrum analysis. But the state's efficiency interest is a genuine variable that will have a measurably different weight in each case. Therefore, the state's interest must determine the position of each case on the spectrum.

By definition, the unified spectrum approach views Elrod as an extreme case, a case in which the balance so clearly favors the employee that no overt balancing is necessary. This view of Elrod suggests that its application should be restricted to narrow circumstances-it is an exception to the general rule that Pickering cases should involve case-by-case balancing. It also suggests that Elrod itself was insignificant, because Pickering would have protected the employee anyway.

Moreover, because the measure is the state's efficiency interest, Elrod must be even narrower: it must apply only when the employee's political affiliation is completely private. Under Pickering, the state's interest is that of "promoting the efficiency of the public services it performs through its employees." cited the effect of the employee's expression on discipline by his immediate supervisors and harmony among his co-workers. ${ }^{82}$ It also considered the effect of the speech on the employee's job performance and on the general operation of the state enterprise. ${ }^{83}$ Similarly, in Connick, the Court pointed to the potential for speech to disrupt a public office and undermine the authority of the employer. ${ }^{84}$ By contrast, a case in which an employee's "objectionable" political affiliation has these effects is difficult to imagine. Therefore, if the state's interest is only that of efficiency, it has a negligible interest in regulating political affiliation, and the balance so favors the employee that Elrod will apply. But when political affiliation combines with overt speech that bolsters the state's interest, Elrod can no longer govern. The unified spectrum approach thus restricts Elrod to the narrow situation in which the

s1 Pickering, 391 US at 568.

${ }^{82}$ Id at $569-70$.

${ }^{83}$ Id at 572-73.

84 Connick, 461 US at 154 . 
employee never speaks about nor advocates her particular affiliation. ${ }^{85}$

One might argue that this narrowing of Elrod is a strength, rather than a weakness, of the unified spectrum approach. Narrowing Elrod in favor of Pickering and Connick lessens the overall protection of public employees' First Amendment rights; ${ }^{86}$ those who stress the government's need to control its employees might favor this development. Nevertheless, such straightforward policy justifications should not be able to overcome binding precedents. To hold otherwise would be to increase the government's authority to fire employees by limiting binding precedent counter to the spirit of that precedent.

This is indeed what the unified spectrum courts have done-they have created an approach that is at odds with the spirit of Elrod, Branti, and Rutan..$^{87}$ These cases represent a clear choice on the part of the Court to make political affiliation dismissals subject to a different standard of scrutiny than speech dismissals. In fact, Justice Scalia's dissent in Rutan objects to the Elrod regime for precisely that reason. ${ }^{88}$ The Rutan Court's rejection of his arguments illustrates how sharply the unified spectrum approach's narrowing effect conflicts with the spirit of the precedents it narrows.

Notably, instead of narrowing the Elrod line of cases, the Supreme Court is in fact moving in the opposite direction. Rutan represents a broadening of the scope of Elrod and Branti to reach patronage practices short of dismissal. Thus, Rutan demonstrates that the Court is moving in the direction of expanding, not narrowing, the scope of the patronage cases.

Bs The courts espousing the unified spectrum approach have in practice restricted it in this fashion. See McBee, 730 F2d at 1012, 1014-15; Jones, 727 F2d at 1334-35 n 6. Jones, however, applies a causation standard that is somewhat more flexible; it holds that Pickering controls only if the employer was influenced "to any significant degree by overt expression." 727 F2d at 1336.

so The unified spectrum's narrow construction of Elrod constricts public employees' First Amendment rights by making more cases subject to the conventional Pickering balancing test. Although Pickering is not unkind to employees, it is less advantageous for nonpolicymakers (the large majority of public employees) than is Elrod, under which they win every time.

${ }^{87}$ Indeed, a dissenting judge in one of the unified spectrum cases argued that this approach "undermines the First Amendment bulwark of Elrod and Branti." McBee, 730 F2d at 1025 (Rubin dissenting).

${ }^{88}$ Rutan, $110 \mathrm{~S} \mathrm{Ct}$ at $2746-47$ (Scalia dissenting). 
3. Internal inconsistency of the unified spectrum approach.

Even if we were to assume that the unified spectrum approach correctly holds that Pickering's standard governs patronage cases and that both Elrod and Pickering examine the same government interest, the spectrum would still lack internal consistency. Admittedly, the inconsistency does not appear when we analyze the rights of nonpolicymakers. As we have seen, the spectrum places nonpolicymakers fired for political affiliation at the far end of the spectrum (on the employee's side), because their exercise of First Amendment rights has little or no effect on office efficiency. So far, this matches what we would expect from Elrod under the unified spectrum approach. The internal tidiness of this wedding of Pickering and Elrod breaks down, however, when one examines the approach's effect on policymakers. Under Elrod, policymaking employees may always be dismissed solely because of their political affiliation, but under Pickering's balancing test the responsibility of the employee's position is simply one factor for the court to consider. Therefore, in order to fit Elrod into the Pickering-based spectrum, a court must hold that policymakers' political affiliation so imperils government efficiency as always to outweigh the employee's First Amendment rights.

We have already seen that political affiliation carries little risk of harming day-to-day office efficiency, ${ }^{89}$ so it is difficult to believe that enough danger exists to justify such a sharp distinction between policymakers and nonpolicymakers. But the problem is even deeper: the unified spectrum's reading of Elrod moves from strained to unworkable when political affiliation combines with overt speech. In the case of a nonpolicymaker, overt speech brings the case outside the narrow reach of Elrod and into the traditional Pickering balance; when the employee speaks, the state's interest is no longer so slight as to fit on the very extreme end of the employee's side of the spectrum. ${ }^{90}$ But what if the employee is a policymaker? For policymakers, the unified spectrum approach should demand the opposite result. Elrod holds that the state's interest in firing a policymaker for mere political beliefs is so strong that any such action is always constitutional. Logically, that interest grows even stronger when the affiliation combines with overt expression. Therefore, if no Pickering balance was necessary absent the overt expression, the presence of that expression should make the bal-

\footnotetext{
89 See text accompanying notes $37-40$.

${ }^{\circ 0}$ See Section II.A.
} 
ance even less necessary. ${ }^{91}$ Nevertheless, unless we ignore Pickering's and Rankin's mandate that the nature of the employee's job is but one factor in the balance, ${ }^{92}$ we cannot avoid applying the Pickering test to a policymaker's overt speech.

Therefore, the unified spectrum view is internally inconsistent. First, in order to place patronage cases within the Pickering standard, it asserts the same governmental interest-efficiency-in firing employees for both speech and political affiliation. Second, in order to justify the categorical test it must accord the state less interest in firing nonpolicymakers for affiliation than for speech. But at the same time, in order to follow the manifest holdings of Elrod and Pickering, it must hold that the state has stronger grounds for firing policymakers solely for their affiliation than it has for firing them either solely for their speech or for their affiliation mixed with speech. We can cure these inconsistencies only by recognizing that Pickering and Elrod do not belong in a single spectrum. Instead, they protect different rights and involve different state interests.

\section{B. Two First Amendment Rights}

We have seen that the spectrum approach is inconsistent both with itself and with the spirit and language of the Court's precedents, and that it unjustifiably narrows the reach of the patronage cases. These problems exist because the proponents of the unified spectrum approach have ignored crucial differences between the two lines of cases in an effort to place Elrod within the domain of Pickering. Therefore, the unified spectrum view is unworkable, and we must advocate some form of the separate tests approach. But what form? What distinguishes Elrod from Pickering?

The language of the Supreme Court's decisions indicates that the distinction between the speech cases and the patronage cases lies in the rights they protect. Pickering holds that a school board may not fire a teacher for exercising his right to free speech-or, more generally, free expression. ${ }^{93}$ In contrast, Elrod and Branti both clearly hold that patronage firings infringe upon the First Amendment rights of freedom of belief and association. For exam-

1 The $M c B e e$ and Jones courts failed to recognize this argument. They held that the specialized Elrod test has no application to cases of mixed speech and affiliation, regardless of whether the employee is a policymaker. McBee, $730 \mathrm{~F} 2 \mathrm{~d}$ at 1014-16; Jones, $727 \mathrm{~F} 2 \mathrm{~d}$ at 1336.

22 See Section I.A.

23 Pickering, 391 US at 574. 
ple, in Elrod Justice Brennan wrote that "[t]he cost of the practice of patronage is the restraint it places on freedoms of belief and association," 94 and in Branti the Court reaffirmed this protection. ${ }^{95}$ After analyzing cases holding that the government could not dismiss a public employee for expression, the majority in Branti held that "[i]f the First Amendment protects a public employee from discharge based on what he has said, it must also protect him from discharge based on what he believes." that Elrod and Branti protect belief, which we may distinguish from the expressive conduct in Pickering.

\section{A fact-based distinction?}

Concededly, establishing that the Court intended Elrod and Branti to govern belief and association does not necessarily mean that it meant to distinguish these rights from the right to free expression. Indeed, one might argue that Elrod and Branti eschew the Pickering balancing test not because the rights at issue differ, but because the cases look different on the facts. For example, the patronage cases generally involve multiple firings after a change of administration, ${ }^{97}$ while the speech cases arise any time the speech occurs-even if the most recent election occurred long ago. ${ }^{98}$ In addition, patronage dismissals result from generalized partisan political concerns, while speech-related firings involve specific incidents of employee behavior. These differences might suggest that even if we decide to adopt separate tests, we should distinguish between the two lines of cases on the facts.

This purely fact-based distinction, however, is less than satisfying because it will not solve the problem of ambiguity between the two lines of cases. Instead, it begs the question: which facts are important? How similar to the facts of Elrod must be the facts of the case at hand before we will select the test in Elrod over the test in Pickering? In practice, courts that have used the separate tests approach have seemed to adopt this fact-based distinction, and they have come to diverse conclusions on this very issue. For

94 Elrod, 427 US at 355. Brennan further states: "Our concern with the impact of patronage on political belief and association does not occur in the abstract, for political belief and association constitute the core of those activities protected by the First Amendment." Id at 356 (footnote omitted).

8s Branti, 445 US at 513 (footnote omitted) (The plurality in Elrod "analyzed the impact of a political patronage system on freedom of belief and association.").

86 Id at 515 (footnote omitted).

97 See, for example, Branti, 445 US at 509.

${ }^{98}$ See, for example, Connick, 461 US at 140-42. 
example, one court has distinguished between Elrod and Pickering on the basis of how many employees were fired. ${ }^{9 \theta}$ Another court has restricted Elrod to cases of party politics, declining to apply the patronage cases to a non-partisan opponent of an elected official. ${ }^{100}$ Neither of these cases clearly explains why these particular facts, and not others, should be determinative.

Instead of distinguishing these cases on the basis of fuzzy fact patterns, a better approach may be available. A "rights-based" distinction between freedom of speech and freedom of association-or, more generally, between freedom of expressive conduct and freedom of belief - could lead to a test with clearer boundaries, a stronger theoretical basis, and much support in the Court's precedents. Therefore, we may be able to explain the different tests in Pickering and Elrod by distinguishing between the rights they protect. If we can do so, we may improve upon the separate tests approach.

\section{Freedom of association.}

The Supreme Court has long distinguished between the right to speak and the right to associate. While freedom of speech appears in the text of the First Amendment, the Supreme Court has inferred freedom of association from rights expressly granted, such as the freedoms of speech, press, and assembly. ${ }^{101}$ That the Court has found it necessary to recognize this implied right demonstrates its belief that the expressed rights do not adequately protect certain First Amendment principles. Indeed, the Court has described the right of association as prior to the right of expression and necessary to its existence. ${ }^{102}$ Citizens frequently associate in order to express their views more effectively; therefore, if the government could control association, it could "stifle the flow of democratic expression and controversy at one of its chief sources."103

\footnotetext{
"2 Terry v Cook, 866 F2d 373, 376-77 (11th Cir 1989) (Elrod applies where an employer fires employees "en masse").

100 Thomas v Carpenter, 881 F2d 828, 831 (9th Cir 1989).

${ }_{102}$ See, for example, Buckley $v$ Valeo, 424 US 1, 15 (1976); NAACP v Alabama, 357 US 449, 460 (1958). See also Ronald D. Rotunda, John E. Nowak, and J. Nelson Young, 3 Treatise on Constitutional Law: Substance and Procedure $\$ 20.41$ at 199-208 (West, 1986); Laurence H. Tribe, American Constitutional Law $\$ 12-26$ at 1010-15 (Foundation, 2d ed 1988).

${ }^{102}$ See Roberts $v$ United States Jaycees, 468 US 609, 622 (1984), ("[a]n individual's freedom to speak, to worship, and to petition the government for the redress of grievances could not be vigorously protected from interference by the State unless a correlative freedom to engage in group effort toward those ends were not also guaranteed.").
}

${ }^{103}$ Wieman v Updegraff, 344 US 183, 191 (1952). 
Furthermore, the Court has explicitly defined the right to free association as separate from (albeit related to) the right to free speech. For example, it has held that the "right of free association [is] a right closely allied to freedom of speech and a right which, like free speech, lies at the foundation of a free society." 104 To say that the two rights are "closely allied" implies that they are not the same right. In addition, freedom of association has appeared in several contexts, ${ }^{105}$ and has its own precedents separate from the freedom of speech cases.

Of the association cases which preceded Elrod, the loyalty oath cases most closely relate to the patronage cases. These precedents define the extent to which a government employer may constitutionally deny employment to persons because of their associations. More precisely, they examine whether and how employment may be conditioned on one's swearing nonaffiliation with certain organizations. ${ }^{106}$ Although a full discussion of the loyalty oath cases is outside the scope of this Comment, it is important to note that the government actions challenged in these cases did not directly infringe upon expression. Instead, they infringed upon the employees' right to free political association-a right that exists whether or not the affected persons express their associational ties. ${ }^{107}$ In other words, the right protected is the right of belief: an employee may believe whatever she wishes, and she may associate herself with whatever group or idea she wishes. While the Court may protect that belief for instrumental reasons, i.e., in order to promote the expression of such beliefs, it is the belief itself which receives direct protection.

This highlights an important difference between the rights of association and speech. For the purposes of associational rights, it is immaterial whether the employee actually expresses her beliefs or associations. By contrast, in Pickering and the other speech

104 Shelton v Tucker, 364 US 479, 486 (1960).

105 See, for example, Roberts $v$ United States Jaycees, 468 US 609 (1984), which involves the freedom not to associate.

${ }^{108}$ Important loyalty oath cases which preceded Elrod include Wieman $v$ Updegraff, 344 US 183 (1952); Shelton $v$ Tucker, 364 US 479 (1960); Elfbrandt v Russell, 384 US 11 (1966); Keyishian v Board of Regents, 385 US 589 (1967); United States v Robel, 389 US 258 (1967); and Cole v Richardson, 405 US 676 (1972).

${ }^{107}$ For example, in Wieman, 344 US at $184 \mathrm{n} 1$, state employees challenged an Oklahoma statute which required them to swear, inter alia, "that I do not advocate, nor am I a member of any party or organization, political or otherwise, that now advocates the overthrow of the Government of the United States ...." The oath did not require that the employee's advocacy or membership be openly expressed;'the belief and association itself were enough to disqualify an individual from state employment. 
cases, it is the expression itself which provokes the government to retaliate, and which the Court seeks to protect. Therefore, in the loyalty oath context, the right at issue differs from the freedom of expression protected in Pickering.

3. Freedom of association in the patronage cases.

Like the right of association in the loyalty oath context, the right to political affiliation protected in Elrod, Branti, and Rutan is a right of belief rather than expression. Indeed, we should view the patronage cases as an outgrowth of the loyalty oath cases, rather than as a relative of the speech cases. For example, while the plurality in Elrod merely mentions Pickering in passing in a footnote, it cites the loyalty oath cases extensively. ${ }^{108}$ This reliance on the loyalty oath cases suggests that the Court viewed the patronage cases as more closely allied to the loyalty oath cases than to the speech cases-a sensible conclusion if the right at issue in the latter differs qualitatively from that at issue in Elrod and Branti.

Furthermore, while the state's interest in Elrod diverges from the efficiency interest advanced in Pickering, there is no such incongruity between Elrod and the loyalty oath cases. In both cases, the state's interest is that of having politically loyal employees. ${ }^{109}$ Significantly, this distinction between efficiency and loyalty helps to demonstrate the deeper distinction between expressive conduct and belief. The efficiency concerns in Pickering, Connick, and Rankin match well with concerns about employee conduct. Because expressive conduct may be overt, noisy, and directly provocative, it can affect the relationships between the employee and her supervisors, co-workers, and employer to a much greater extent than mere belief. Furthermore, expressive conduct can impair office efficiency by distracting the enterprise from public service. Belief does not by itself distract.

On the other hand, political loyalty inherently lies in the realm of subjective belief and association. Although many people tend to act in accordance with their beliefs, the word "loyalty" implies a certain mental condition which exists regardless of conduct. It follows that the government's interest in having politically loyal

\footnotetext{
108 See, for example, Elrod, 427 US at 365, citing Wieman, 344 US 183; Elfbrandt, 384 US 11; and Keyishian, 385 US 589. Citations to these and other freedom of association cases appear throughout the Elrod plurality opinion.

${ }^{109}$ See Wieman, 344 US at 188 ("we have had occasion to consider legislation aimed at safeguarding the public service from disloyalty").
} 
subordinates is an interest in regulating belief. In the patronage cases, even though the government may fire the employee to guard against conduct which threatens its policies, it is the belief itself that prompts the employer to act.

This distinction between expressive conduct and belief is the true difference between the two lines of cases. Over the years, the Court has inferred a right of free association for the specific purpose of protecting political beliefs and associations that have not yet been expressed or that the government has abridged directly without regard to whether they have been overtly expressed. By contrast, the Court has looked to the right to free speech to protect the overt expression that the government wishes to abridge or penalize. These distinguishable rights of belief and speech in Elrod and Pickering respectively implicate the distinct government interests of political loyalty and efficiency. The difference between these interests, in turn, creates the need for separate tests in the patronage and speech contexts. It should also not be surprising that Elrod gives the employee greater protection than does Pickering. Given that the Court views associational rights as a necessary precondition of speech rights, and given that belief and association are one step further than speech from conduct dangerous to the state, association should receive greater immunity from state regulation. The test in Elrod may reflect the attitude that belief and association are both more fundamental to the free exchange of ideas and less dangerous to the state than speech.

Therefore, it is these different First Amendment rights that distinguish the two lines of cases from one another. We can now undertake to create a framework for determining which right is implicated in an ambiguous case.

\section{SCOPe of ElRod ANd Pickering}

A. Making the Rights-Based Distinction

Once we conclude that Pickering and Elrod govern different rights, the logical extension is to apply Pickering whenever the state fires an employee for expressive conduct, and to apply Elrod whenever the state fires an employee for holding political beliefs contrary to those of her employer. In an ambiguous case, we should try to determine what caused the employer to fire his employee-was it the employee's expression itself, or rather the em- 
ployee's political beliefs (perhaps as revealed in the content of that expression)? ${ }^{110}$

On this count, the facts of Branti $v$ Finkel, ${ }^{111}$ the second patronage decision, provide an instructive example. Branti, the newly-appointed public defender, fired six of the nine employees left over from the previous administration. All six belonged to the political party of the previous public defender; the three employees retained were members of Branti's own party. ${ }^{112}$ In that case, the district court readily concluded that Branti had dismissed the employees on the basis of their political affiliation. ${ }^{113}$

But let us alter the facts slightly. Imagine that of the six who lost their jobs, two of the fired employees had actively campaigned against Branti and the other four had not. Here, since Branti fired the non-expressive employees along with the expressive ones, the cause of the firings was still affiliation and not speech. On the other hand, if Branti was aware of the political affiliations of the four who did not campaign but fired only the two employees who campaigned actively, then his motivation in firing was probably expression. We know this because the four employees who shared the political affiliation, but not the speech, of the fired employees nonetheless retained their jobs.

The Paula Partisan hypothetical with which I began this Comment presents a more ambiguous case. Remember that Paula said, "[a]s a member of the Platypus Party of America, I support Ida Incumbent over Carl Contender," and we can assume that this statement led to her dismissal. To determine which test to apply, we must ask the following question: Did Carl fire Paula because of the expression itself, which might have offended Carl or led him to think her speech would sour office relationships, or did he fire her because the statement revealed that she was a member of the Platypus Party? If the former, then Pickering applies; if the latter, then Elrod is the appropriate test.

As in the Branti example, we might uncover Carl's motivations by looking at whether he fired any other employees. If Carl fired everyone he knew to be a member of the Platypus Party, then

110 Although we may often have difficulty distinguishing between possible causes of a firing in an individual case, particularly when an employee loudly expresses her political beliefs, we should not be daunted by this complication. Indeed, it is always difficult in employment cases, where the employer's motivation is commonly ambiguous, to gauge the true cause of an employee's dismissal.

11445 US 507 (1980).

112 Id at 509-10.

113 Id at 510. 
he probably also fired Paula for that same reason. On the other hand, if Carl retained other known members of the Platypus Party, then he probably fired Paula for her expression. However, if Paula was the only known member of the Platypus Party or if Carl fired some Platypi but not others, the factfinder will face a more difficult task. But at least we know the right question to ask, even if that question will not always be easy to answer: Was Paula fired for her conduct, or was she fired for her beliefs?

\section{B. The Ramifications of the Rights-Based Distinction}

This view of Elrod and Pickering as separate tests governing separate rights leads to a broader application of Elrod than the unified spectrum approach. Because Elrod applies to patronage dismissal cases which infringe the rights of belief and association, we need not limit its reach to cases that do not involve any overt expression. Instead, Elrod will apply whenever the state discharges an employee for reasons of belief or association, even if the employee incidentally manifested her views or loyalties. Of course, we should be wary of situations that bear no factual resemblance to the patronage cases. The right to free association is broader than the reach of Elrod and, although the patronage cases may be relevant precedent, they do not govern every aspect of that right. They do not, for instance, supersede the loyalty oath cases or other fact situations directly governed by other existing precedent.

Nonetheless, where a dismissal for belief and association does not fall directly under some other precedent, courts should not mechanically confine the scope of the patronage cases to the facts of Elrod and Branti. For example, a court should not hesitate to apply Elrod to a case in which an employer discovers an employee's objectionable political affiliation and fires her for that affiliation halfway through the employer's term in office. Although Elrod specifically addresses patronage firings of the ordinary variety-those that occur immediately after a change in administration-the same considerations exist when the firing occurs later, as long as the same unconstitutional motivation engendered the dismissal.

\section{Proposed Causation Test}

The court hearing Paula Partisan's case will have to determine the exact cause of her firing: it will have to decide between two 
potentially unconstitutional reasons for dismissal. ${ }^{114}$ Although the Supreme Court has not heard a case similar to Paula's, its opinion in Mt. Healthy City Board of Education v Doyle ${ }^{115}$ provides a test for causation in cases of "mixed motive." Mixed motive cases arise when an employer dismisses an employee and the court must ascertain whether the reason for dismissal was a constitutionally protected interest or some form of misconduct for which the employer could legally fire his employee. ${ }^{116}$ In Mt. Healthy, a school board declined to renew the contract of one of its teachers. ${ }^{117}$ Its action was due, in part, to the teacher's expression; like Pickering, Doyle had complained to the media about school board policy. ${ }^{118}$ The school board was also unhappy with Doyle because of several incidents of conduct that were not protected by the First Amendment. ${ }^{119}$ This was a classic case of mixed motive.

In an opinion by Justice Rehnquist, the Court held that in such a case the plaintiff-employee bears the initial burden of showing that the protected speech was a "substantial" or "motivating" factor in the employer's decision to fire him. ${ }^{120}$ If the plaintiff meets this burden, then the defendant-employer must show that it would have taken the same action against the employee even had the protected expression not occurred.121 Only if the employee meets his burden and the employer fails to do likewise will the Pickering test apply.

My proposed test for deciding between two impermissible motivations for dismissal borrows from this $M t$. Healthy test for deciding between a permissible and an impermissible motivation. To illustrate the mechanics of this test, let us return again to Partisan $v$ Contender. Carl may have fired Paula because of her political affiliation with the Platypus Party, or because she spoke openly

114 The unconstitutional reasons are, of course, speech and affiliation. In practice, the employer will usually argue that he fired Paula for a permissible reason-for example, because she had a poor record for punctuality-in order to escape liability under both Pickering and Elrod.

116429 US 274 (1977).

${ }^{116}$ Mixed motive cases also frequently arise in employment contexts other than the First Amendment. See, for example, NLRB v Transportation Management Corp., 462 US 393 (1983) (alleged firing for union activities in violation of the National Labor Relations Act); Price Waterhouse $v$ Hopkins, 490 US 228 (1989) (alleged firing on the basis of sex discrimination).

11 Mt. Healthy, 429 US at 282.

118 Id at 281-82.

118 Id at 281-83.

120 Id at 287.

121 Id. 
to the press against Carl Contender, or for some combination of these reasons. How do we decide?

We must first inquire whether the employee was a "policymaker"-in Branti's terms, an employee for whom political affiliation would be a reasonable job requirement. The court should resolve this as a question of law, because the inquiry involves policy concerns and relies upon precedent that a jury would have difficulty understanding. ${ }^{122}$ The court should determine the employee's status at the outset because the resolution of this issue will determine the positions of the parties. For example, should the court determine that Paula is a policymaker, Paula will prefer the Pickering test over the Elrod test; thus she will argue that Carl dismissed her for her words to the press, and not because of her political affiliation. If, on the other hand, the court should determine that Paula is not a policymaker, she will argue for the Elrod test.

The next inquiry parallels the procedure in Mt. Healthy. Let us assume that the court determines that Paula was a policymaker. Paula will argue that speech rather than mere political affiliation prompted her dismissal, because policymakers cannot recover under Elrod. Such a claim calls for a straightforward application of $M t$. Healthy: Paula carries the initial burden of proving that her overt speech was a substantial or motivating factor in Carl's decision. If she succeeds, Carl must prove that he would have reached the same decision even had she never spoken to the press. If Paula meets her burden, and Carl fails to meet his, the court must apply the Pickering balance.

Now let us assume that the court determines that Paula was not a policymaker. She may try to recover under either Elrod or Pickering. She will prefer Elrod, however, because under that test Carl's action is presumptively unconstitutional. ${ }^{123}$ Therefore, Paula will bear the initial burden of proving that her political beliefs were a substantial or motivating factor in Carl's decision. If she meets this burden, Carl will have to prove that he would have made the same decision even if Paula shared his beliefs. If Carl fails to convince the factfinder, then Elrod applies and Paula will prevail.

122 In fact, courts regularly decide this question as a matter of law. Jimenez Fuentes $v$ Torres Gaztambide, 807 F2d 236, 239-47 (Ist Cir 1986) (court considered generally whether the position relates to partisan political concerns and the inherent powers and privileges of the position of regional director of civil rights office).

${ }^{123}$ Elrod, 427 US at $372-73$. 
However, in this second case, if Carl successfully proves that he would have fired Paula regardless of her affiliation, Paula can press the Pickering claim. Again, the court will apply Mt. Healthy. Paula must prove that her overt speech was a substantial or motivating factor in Carl's decision. If she succeeds, Carl must prove that he would have fired her for some permissible reason regardless of her speech. If Carl succeeds in proving this, he will prevail; if he fails, the court must apply the Pickering balance.

\section{ConCLUSION}

Both Elrod and Pickering potentially apply to cases in which a public employer fires an employee for exercising her First Amendment rights. However, the patronage cases and the overt speech cases govern different First Amendment rights and implicate different state interests. Therefore, courts should apply them separately to cases that involve the appropriate rights and interests.

The test from the patronage cases should apply to discharges for political beliefs and associations. By contrast, the balancing test from the speech cases should apply to firings for overt expression. The courts can best serve this approach by using a modification of the Mt. Healthy causation test in mixed motive cases. The Mt. Healthy test provides a procedure for determining causation consistent with the Supreme Court's method in other First Amendment cases.

This approach would provide a sensible and workable framework for differentiating between the two lines of Supreme Court authority and applying them to ambiguous cases. At the same time, it would prevent the misguided narrowing of public employees' First Amendment rights. If adopted, it would thus promote the freedom of citizens while reducing confusion among the courts. 


,

